\title{
Oxidation Resistance Analysis Of Metallic (FeCrAl Foil) Catalytic Converter Developed By Ultrasonic Approach
}

\author{
A.M Leman ${ }^{1}$, Dafit Feriyanto ${ }^{1}$, N. Farhana ${ }^{1}$, R. Rahmat ${ }^{1}$, B.A. Bakar ${ }^{1}$, and I. Baba ${ }^{1}$ \\ ${ }^{1}$ Faculty of Engineering Technology, Universiti Tun Hussein Onn Malaysia (UTHM), \\ Parit Raja, Batu Pahat, 86400 Johor, Malaysia.
}

\begin{abstract}
Mobile sources contribute about $44 \%$ of outdoor toxic emissions, approximately $50 \%$ of cancer risk and at around $74 \%$ of noncancer risk health problems. Catalytic converter is quite needed in removing the pollutant and in preventing a health problem. The main problem in the catalytic converter is low oxidation resistance when operated at high temperature. Therefore, this paper aimed to develop catalytic converter material in high-temperature operation at around 1100 ${ }^{\circ} \mathrm{C}$ using $\mathrm{FeCrAl}$ foils as a metallic catalytic converter which coated by $\gamma$ Al2O3. This research is conducted using 3 various techniques such as ultrasonic bath for 3, 4, and 5 hours, Nickel (Ni) electroplating for 30, 45 and 60 minutes and the combination of ultrasonic bath and electroplating technique. Oxidation resistance analysis was conducted using tube furnace under argon gas for 60 hours in 3 cycles. Mass changes analysis of treated samples is showed by degradation mass. Lowest mass change of by ultrasonic bath samples is $0.3 \mathrm{wt} \%$, for a combination of ultrasonic and electroplating samples is $0.3 \mathrm{wt} \%$ shown by UT 3 hours as well as 0.6 shown by EP $30 \mathrm{~min}$. Parabolic rate constant is obtained by the time calculation based on the mass change of treated and untreated samples. It shown that UB $3 \mathrm{~h}$ is lowest parabolic rate constant of $2.258 \times 10-20 \mathrm{~g} 2$ $\mathrm{cm}-4 \mathrm{~s}-1$ and UB $5 \mathrm{~h}$ is $1.13 \times 10-20 \mathrm{~g} 2 \mathrm{~cm}-4 \mathrm{~s}-1$. Lowest mass gain and lowest parabolic rate constant are become an indicator that the samples and that technique are recommended to fabricate the catalytic converter.
\end{abstract}

\section{Introduction}

Nowadays, there are many problems in our environment contributed by transportation sector especially from motor vehicle [1]. According to Malaysia Environmental Quality Report there are many types of pollutants which release by normal engine operation condition such as Carbon Monoxide (CO, 0.5 vol. \%), Unburned Hydrocarbons (HC, 350 vppm), Nitrogen Oxides $\left(\mathrm{NO}_{\mathrm{x}}, 900\right.$ vppm), Hydrogen $\left(\mathrm{H}_{2}, 0.17\right.$ vol. \%), Water $\left(\mathrm{H}_{2} \mathrm{O}, 10\right.$ vol. \%), Carbon dioxide $\left(\mathrm{CO}_{2}, 10\right.$ vol. \%), Oxygen $\left(\mathrm{O}_{2}, 0.5\right.$ vol. \%). According to these data, $\mathrm{HC}, \mathrm{CO}$ and $\mathrm{NO}_{\mathrm{x}}$ are the major pollutants that influence to the outdoor toxic emission,

\footnotetext{
*Corresponding author : mutalib@uthm.edu.my
} 
cancer risk and non-cancer risk health problem $[2,3]$. They reaction are mentioned in Eq 1, 2 and 3 [4].

$$
\begin{gathered}
2 \mathrm{CO}+\mathrm{O}_{2} \rightarrow 2 \mathrm{CO}_{2} \\
\mathrm{C}_{\mathrm{x}} \mathrm{H}_{2 \mathrm{x}}+2+[(3 \mathrm{x}+1) / 2] \mathrm{O}_{2} \\
\rightarrow \mathrm{xCO}_{2}+(\mathrm{x}+1) \mathrm{H}_{2} \mathrm{O} \\
2 \mathrm{NO}_{\mathrm{x}} \rightarrow \mathrm{xO}_{2}+\mathrm{N}_{2}
\end{gathered}
$$

These three reactions occur most efficiently when the catalytic converter receives the exhaust gas from an engine running slightly above the stoichiometric point. In below of stoichiometric point shows the necessary mixing rate of the most common fuels [4].

The technology of vehicle emission reduction can be categorized into two major parts, namely primary and secondary method. For the primary method, it depends on fuel used by vehicle based on air treatment and combustion process. In the meantime, the use of a catalytic converter in the exhaust system of vehicles is the secondary method [4]. These studies focus on the catalytic converter as vehicle emission reduction by new treated material. There are 2 major material types for catalytic converter which are ceramic and metallic material. Generally, physical parameter of the catalytic converter is listed in Table 1.

Table 1. Physical Parameters of the Converter [5].

\begin{tabular}{|l|l|}
\hline \multicolumn{2}{|c|}{ Physical parameters of the converter } \\
\hline Wall density & $2500 \mathrm{~kg} / \mathrm{m}$ \\
\hline Wall thermal conductivity & $2 \mathrm{~W} / \mathrm{mK}$ \\
\hline Wall heat capacity & $1400 \mathrm{~J} / \mathrm{kgK}$ \\
\hline Elective wall thickness & $0.25 \mathrm{~mm}$ \\
\hline Thickness of washcoat layer & $0.05 \mathrm{~mm}$ \\
\hline Porosity of washcoat & 0.41 \\
\hline Channel hydraulic diameter & $1.4 \mathrm{~mm}$ \\
\hline Channel open frontal area & $1.96 \mathrm{~mm}$ \\
\hline Porosity of monolith & $72 \%$ \\
\hline
\end{tabular}

First catalytic converter is developed using ceramic honeycomb substrate which based on cordierite $\left(2 \mathrm{MgO} \cdot 2 \mathrm{Al}_{2} \mathrm{O}_{3} \cdot 5 \mathrm{SiO}_{2}-14 \% \mathrm{MgO}, 35 \% \mathrm{Al}_{2} \mathrm{O}_{3}\right.$ and $\left.51 \% \mathrm{SiO}_{2}\right)$. That material is selected because they it has many advantages in softening points with higher attrition resistance, high melting, and lower pressure losses, low thermal expansion, high shock resistance as compared to pallet converter [6]. start from the 1970s, honeycomb substrate with ultra thin foil, corrugated and laid up is developed by ferritic steel which called by $\mathrm{FeCr}$ alloy. It consists of Iron $(\mathrm{Fe})$, Chromium $(\mathrm{Cr})$, Aluminum $(\mathrm{Al})$ and Yttrium $(\mathrm{Y})$. It protected by Alumina $\left(\mathrm{Al}_{2} \mathrm{O}_{3}\right)$ in order to achieve the withstand high temperature and corrosive condition in exhaust [7]. Metallic and ceramic catalytic converter is shown in Figure 1. 


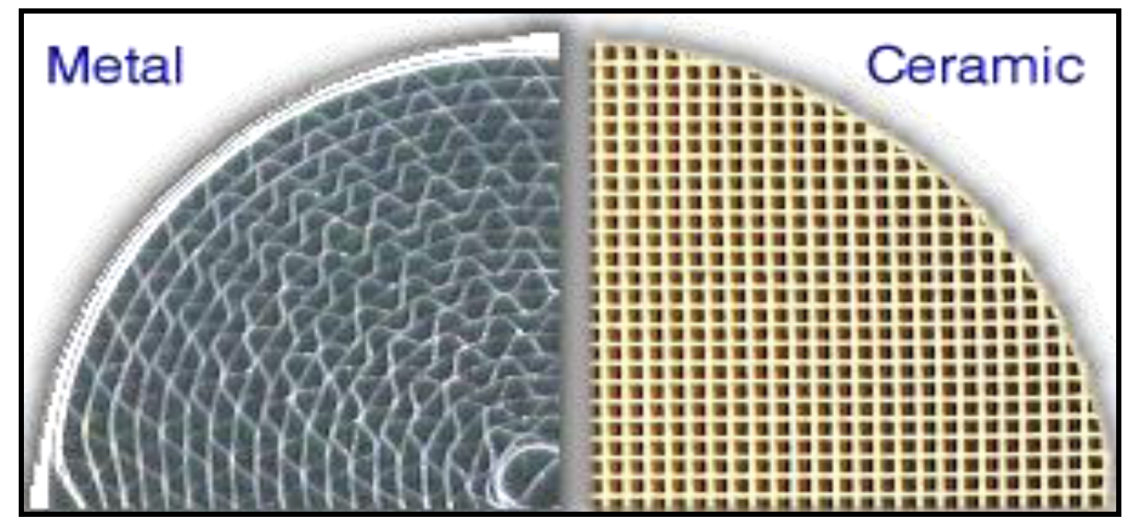

Fig. 1. Ceramic and metallic substrate converter [7].

The metallic catalytic converter has many promising properties such as high melting, high cell densities, high thermal shock resistance and low-pressure losses. But it has more advantages as compared to ceramic material in physical properties i.e. low specific heat and cheap (low-cost fabrication) [1]. Nowadays, FeCrAl is the promising metallic catalytic converter because it has excellent oxidation resistance at a high temperature of $1300{ }^{\circ} \mathrm{C}$ [8] and it commonly coated by $\gamma-\mathrm{Al}_{2} \mathrm{O}_{3}$ powders as corrosion and oxidation protective [9]. It used as coated material because the low price, good chemical stability, high micro-hardness and wear resistance at high temperature [10]. Other material such as $\mathrm{Pt}, \mathrm{Rh}$ and $\mathrm{Pd}$ is not used in this research because it sensitive to thermal degradation at high temperature, $\mathrm{CeO}_{2}-$ Mn because it trapping of sulfur which led to corrosion [12].

Therefore, In this research is conducted using FeCrAL foil as substrate and $\gamma-\mathrm{Al}_{2} \mathrm{O}_{3}$ powders as wash coat material in order to achieve high oxidation resistance treated by ultrasonic approach. That treatment is chosen because during the ultrasonic process, highspeed bubbles producing a jet of liquid moving at around $100 \mathrm{~m} / \mathrm{sec}$. High velocity a jet potential to applied for cleaning, removing impurities from spent catalyst, electroplating or surface treatment process [13], and predicted to catalyst activation after and during coating process.

\section{Methodology}

Coating activity in this research is conducted using an ultrasonic approach which divided into three signed methods which are ultrasonic bath, nickel (Ni) electroplating and the combination of ultrasonic bath and electroplating technique. The material used in this research such as FeCrAl foil, $\gamma$-Al2O3, Ni plate, Nickel Sulphamate $\left(\mathrm{Ni}\left(\mathrm{SO}_{3} \mathrm{NH}_{2}\right) 2.4 \mathrm{H}_{2} \mathrm{O}\right)$, nickel chloride $\left(\mathrm{NiCl} \cdot 6 \mathrm{H}_{2} \mathrm{O}\right)$, boric acid $\left(\mathrm{H}_{2} \mathrm{BO}_{3}\right)$, and sodium Lauryal Sulphate $\left(\underline{\mathrm{C}}_{12} \underline{\mathrm{H}}_{25} \underline{\mathrm{SO}}_{4} \underline{\mathrm{Na}}\right)$ Natrium Hydroxide $(\mathrm{NaOH})$.

\subsection{Ultrasonic Bath Process}

Ultrasonic bath technique is purposed to the preliminary coating process of $\gamma-\mathrm{Al}_{2} \mathrm{O}_{3}$ to FeCrAl foil. FeCrAl foil is being cut in the size of $30 \times 15 \mathrm{~mm}$. Ethanol with a concentration of $20 \mathrm{~g} / \mathrm{l}$ is used as coating media in order to accelerate the $\gamma-\mathrm{Al}_{2} \mathrm{O}_{3}$ ebbed into the $\mathrm{FeCrAl}$ foil. Ultrasonic bath process is conducted using frequency of $35 \mathrm{kHz}$ in various times of 3, 4, and 5 hours. The mechanism of the ultrasonic bath is shown in Figure 2. 


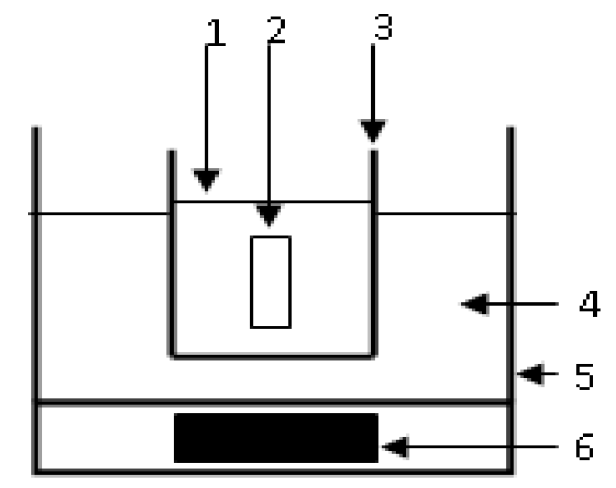

Fig. 2. Schematic diagram of ultrasonic cleaning bath (1) Ethanol; (2) FeCrAl; (3) Beaker; (4) Water; (5) Bath; (6) Ultrasonic source.

\subsection{Nickel (Ni) Electroplating Process}

In electroplating process, there are several components that are needed to be concern such as electrolyte (sulphamate type), anti-pitting agent, anode and cathode. The electrolyte is prepared by employing distilled water at a constant temperature of $60{ }^{\circ} \mathrm{C}$ and the adjustment of the $\mathrm{pH}$ value around 2.5-5.4 by manipulating the $\mathrm{HCl}$ and $\mathrm{NaOH}$ as the reagent. Ni plate is positioned as an anode and $\mathrm{FeCrAl}$ as the cathode with distance approximately of $25 \mathrm{~mm}$ with the current density of $2 \mathrm{~A} / \mathrm{dm}^{2}$ and total surface area of 450 $\mathrm{mm}^{2}$. Illustration of the schematic diagram of the electroplating process is shown in Figure 3 and electroplating reaction is shown in Figure 4.

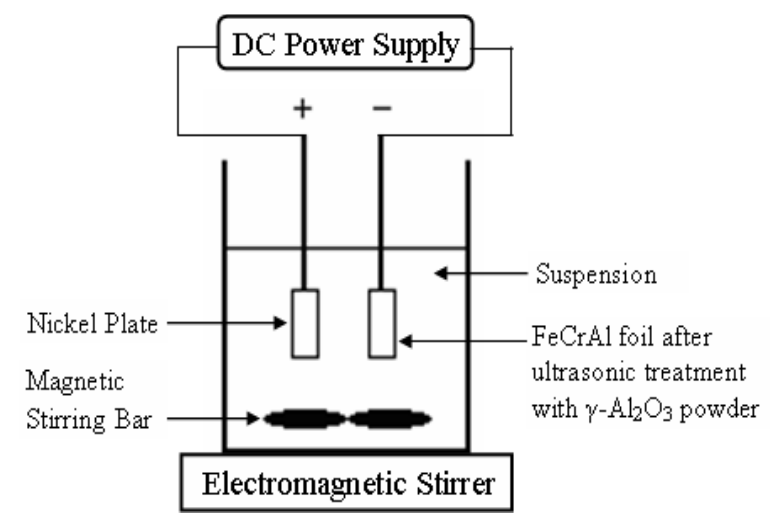

Fig. 3. Schematic diagram of electroplating process. 


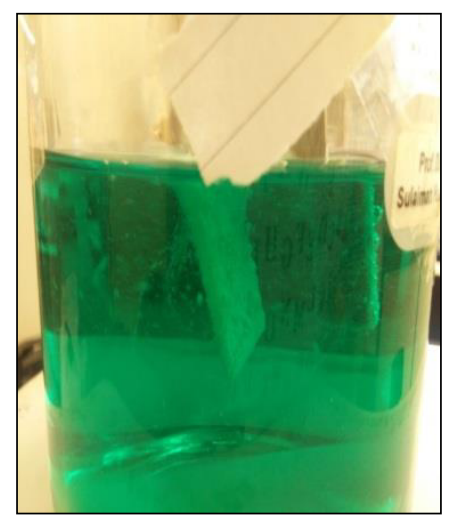

Fig. 4. The reaction occurs during electroplating.

\subsection{Oxidation test}

Tube furnace is held under argon gas environment at the temperature of $1100^{\circ} \mathrm{C}$ with heating and cooling rate of $5{ }^{\circ} \mathrm{C} / \mathrm{min}$, argon gas flow rate of $51 \mathrm{ml} / \mathrm{min}$ and flow density of $3.98 \mathrm{~g} / \mathrm{ml}$. The experiment was designed at 3 cycles and each cycle was carried out during $20 \mathrm{~h}$ of saturated period. Prior to, the material mass was measured by an electronic microbalance with the precision of $0.001 \mathrm{~g}$. After oxidation test, the data is measured by Eq. 3 and Eq. 4.

Where;

$$
\Delta W=\frac{W_{1}-W_{1}}{A_{1}}
$$

$W t=$ Sample weight after each cycles of the oxidation process.

$W i=$ Initial weight sample

$A i=$ The surface area of the sample before oxidation process.

The calculation for the parabolic rate constant $(\mathrm{kp})$ using parabolic rate law

Where;

$$
\left(\frac{\Delta W}{A_{1}}\right)^{2}=k_{p} t
$$

$t=$ The oxidation time (s)

$k_{p}=$ The parabolic rate constant $\left(\mathrm{g}^{2} \mathrm{~cm}^{-4} \mathrm{~s}^{-1}\right)$

\section{Result and Discussion}

\subsection{Mass Changes}

Mass change analysis is used to observe the oxidation resistance or thermal stability of the material. the effectiveness of the method to improve the oxidation resistance is signed by small mass change. Mass change of the ultrasonic bath and combination of ultrasonic and electroplating technique samples is listed in Table 2. It shows that the smallest mass change is signed by UB 5 hours in 3rd cycles with no mass change observed compared to UB 3 and 4 hours with $0.3 \mathrm{wt} \%$ mass change in every step. For UT samples show that different pattern with UB samples where the UT 5 hours shows the highest mass change of 2.167 $\mathrm{wt} \%$ as compared to UT 3 hours of $0.3 \mathrm{wt} \%$ and UT 4 hours of $0.9 \mathrm{wt} \%$. Longer time of 
ultrasonic bath technique is led to the higher amount of $\gamma-\mathrm{Al}_{2} \mathrm{O}_{3}$ which embed in $\mathrm{FeCrAl}$ foil. $\gamma-\mathrm{Al}_{2} \mathrm{O}_{3}$ layer is proposed heat resistance before it spread into the $\mathrm{FeCrAl}$ foil. That phenomenon is not valid when the ultrasonic bath is combined with electroplating technique. It maybe caused by different liquid media where the ultrasonic bath use ethanol and electroplating use sulphamate type as solution. Different concentration is given high impact to the process of $\gamma-\mathrm{Al}_{2} \mathrm{O}_{3}$ to embed into $\mathrm{FeCrAl}$ foil.

Table 2. Mass changes of treated and untreated samples.

\begin{tabular}{|c|c|c|c|}
\hline \multicolumn{5}{|c|}{ The mass of sample after oxidation test for ultrasonic bath sample } \\
& $\begin{array}{c}\text { Mass change of } \\
\text { UB for 3 Hours }\end{array}$ & $\begin{array}{c}\text { Mass change of } \\
\text { UB for 4 Hours }\end{array}$ & $\begin{array}{c}\text { Mass change of } \\
\text { UB for 5 Hours }\end{array}$ \\
\hline Initial & $0.319 \mathrm{~g}$ & $0.325 \mathrm{~g}$ & $0.32 \mathrm{~g}$ \\
\hline Cycle 1 & $0.319 \mathrm{~g}$ & $0.325 \mathrm{~g}$ & $0.32 \mathrm{~g}$ \\
\hline Cycle 2 & $0.318 \mathrm{~g}$ & $0.324 \mathrm{~g}$ & $0.319 \mathrm{~g}$ \\
\hline Cycle 3 & $0.317 \mathrm{~g}$ & $0.323 \mathrm{~g}$ & $0.319 \mathrm{~g}$ \\
\hline The mass of the sample after the oxidation test for ultrasonic bath \\
followed by electroplating sample (UT)
\end{tabular}

The main coating process of this research is using Nickel electroplating technique. It aimed to improve the surface properties of $\mathrm{FeCrAl}$ by coating $\gamma$-Al2O3 such as to improve wear resistance, corrosion protection and oxidation resistance. This research is focused on developing high oxidation resistance of the treated FeCrAl sample which approved by small mass change after electroplating like shown in Figure 5.

Mass change analysis of treated samples shows the improvement properties hightemperature operation of $1100{ }^{\circ} \mathrm{C}$. Electroplating (EP) for 30 minutes shown highest oxidation resistance by smallest mass changes of $0.6 \mathrm{wt} \%$ as compared to EP $45 \mathrm{~min}$ of $15.34 \mathrm{wt} \%$ and EP $60 \mathrm{~h}$ of $13.92 \mathrm{wt} \%$. in these case, the mass changes increase linearly with the electroplating times. EP $30 \mathrm{~min}$ have higher deposition rate which provides uniformity of coating thickness and compact deposit are synthesized in template-based structure. 


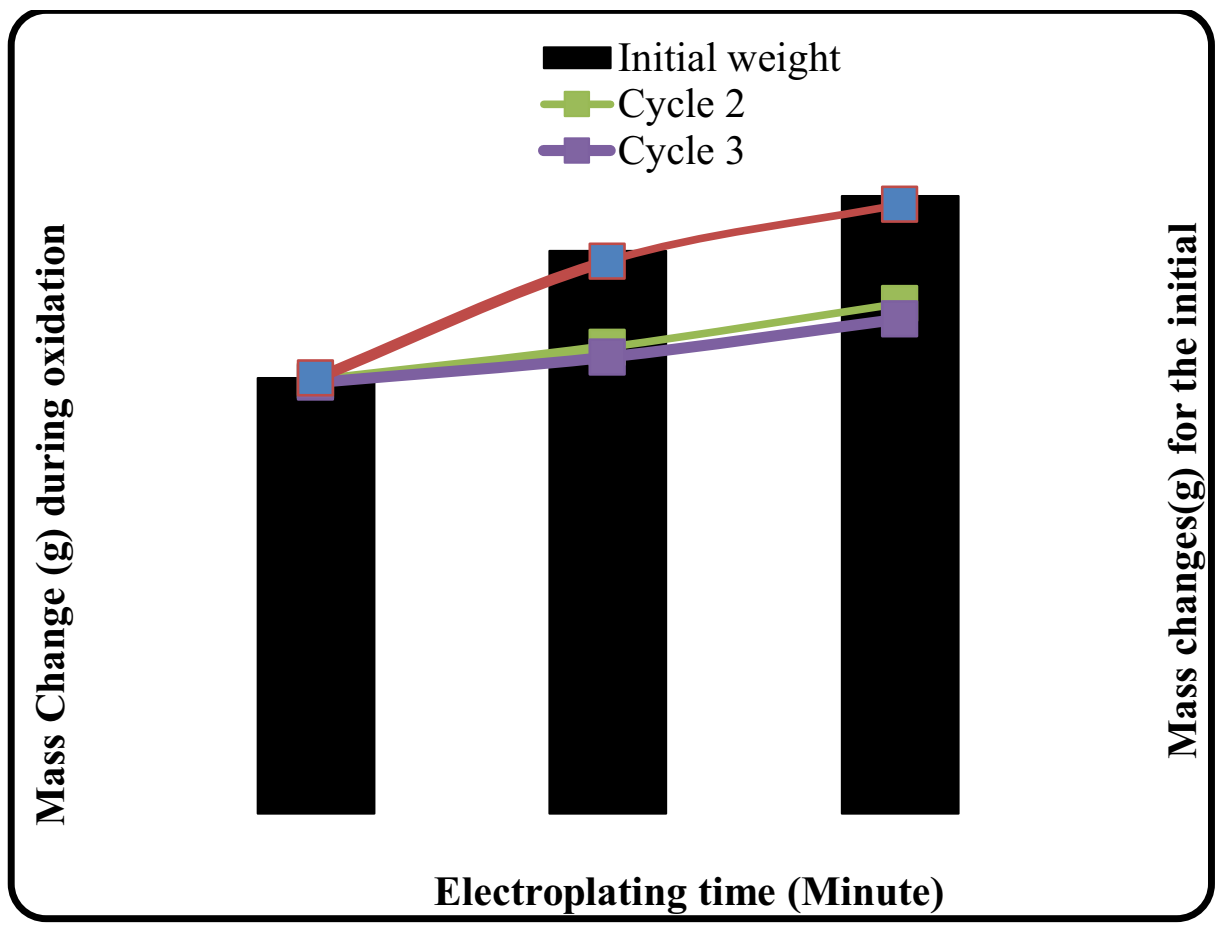

Fig. 5. Mass change of treated and untreated samples after electrodeposition process.

\subsection{Parabolic Rate Constant}

The parabolic rate constant is an intrinsic property of an oxidation resistant and normally used to measure its oxidation resistance. The parabolic rate constant of treated and untreated samples is listed in Table 3. Preliminary coating by UB 3 hours is obtain 2.258 $\mathrm{x} 10-20 \mathrm{~g}^{2} \mathrm{~cm}^{-4} \mathrm{~s}^{-1}$ which compared to UB $4\left(9.14 \times 10-09 \mathrm{~g}^{2} \mathrm{~cm}^{-4} \mathrm{~s}^{-1}\right)$ and 5 hours $(1.13 \times 10$ $\left.20 \mathrm{~g}^{2} \mathrm{~cm}^{-4} \mathrm{~s}^{-1}\right)$. The samples after a combination of ultrasonic bath and electroplating which signed by UT samples shown inline phenomena with UB samples. Where the UT $3 \mathrm{~h}$ shown lowest parabolic rate constant of $\left.3.387 \times 10-20 \mathrm{~g}^{2} \mathrm{~cm}^{-4} \mathrm{~s}^{-1}\right)$ as compared to UT $4 \mathrm{~h}$ (1.829 x10-18 $\left.\mathrm{g}^{2} \mathrm{~cm}^{-4} \mathrm{~s}^{-1}\right)$ and UT $5 \mathrm{~h}$ of $\left(2.729 \times 10-17 \mathrm{~g}^{2} \mathrm{~cm}^{-4} \mathrm{~s}^{-1}\right)$. Smallest mass change of EP $3 \mathrm{~h}$ effect to the lower parabolic rate constant for $\left.7.968 \times 10-14 \mathrm{~g}^{2} \mathrm{~cm}^{-4} \mathrm{~s}^{-1}\right)$ and higher kp shown by EP $4 \mathrm{~h}\left(4.27 \times 10-13 \mathrm{~g}^{2} \mathrm{~cm}^{-4} \mathrm{~s}^{-1}\right)$ and EP $5 \mathrm{~h}\left(1.89 \times 10-12 \mathrm{~g}^{2} \mathrm{~cm}^{-4} \mathrm{~s}^{-1}\right)$. All the results shows that 3 hours treatment times is most effective by ultrasonic bath, electroplating and combination of ultrasonic and electroplating technique.

Parabolic rate constant is remarkably reduced in 3 hours treatment times by spinel protection coating because it provided by $\gamma-\mathrm{Al}_{2} \mathrm{O}_{3}$ oxide scale. From the results of oxidation test that coated material shown an excellent resistance against the spallation and cracking which resulted by lower mass change and lower parabolic rate constant. Spalling and cracking phenomena commonly due to the oxide of coefficient of thermal expansion is mismatching [16]. 
Table 3. The parabolic rate constant for an ultrasonic bath.

\begin{tabular}{|c|c|}
\hline Treatment & Average $\left(\mathrm{g}^{2} \mathrm{~cm}^{-4} \mathrm{~s}^{-1}\right)$ \\
\hline UB 3Hours & $2.258 \times 10^{-20}$ \\
\hline UB 4Hours & $9.14 \times 10^{-09}$ \\
\hline UB 5Hours & $2.258 \times 10^{-20}$ \\
\hline UT 3Hours & $3.387 \times 10^{-20}$ \\
\hline UT 4Hours & $1.829 \times 10^{-18}$ \\
\hline UT 5Hours & $2.729 \times 10^{-17}$ \\
\hline EP 3Hours & $7.968 \times 10^{-14}$ \\
\hline EP 4Hours & $4.27 \times 10^{-13}$ \\
\hline EP 5Hours & $1.89 \times 10^{-12}$ \\
\hline
\end{tabular}

\subsection{Statistical analysis}

Statistical analysis is performed for all method in order to investigate the significance of parameter which applied in this research. Analysis of Variance (ANOVA) single factor is used to analyze the data. For electroplating results (Table 4) shows that the Fcrit of 4.066181 is bigger than $\mathrm{F}$ of 1.041539 means that this method is significant in changing the properties. Current density, sulphamate type, $\mathrm{pH}$, and electroplating times give high effect to the improving oxidation resistance in high temperature of $1100^{\circ} \mathrm{C}$.

Table 4. Statistical analysis of after electroplating process (EP).

\begin{tabular}{|l|r|c|c|c|}
\hline Source of Variation & \multicolumn{1}{|c|}{$d f$} & $M S$ & $F$ & $F$ crit \\
\hline Between Groups & 3 & 0.002496 & 1.041539 & 4.066181 \\
\hline Within Groups & 8 & 0.002397 & & \\
\hline Total & 11 & & & \\
\hline
\end{tabular}

Ultrasonic bath (Table 5) and the combination of ultrasonic bath and electroplating (Table 6) shown that the parameter conducted in those process is a significant effect to the oxidation resistance properties. It approved by statistical analysis which mentions that value of Fcrit $>$ F. Ultrasonic bath obtains Fcrit of 4.120312 and F of 0.130165 meanwhile for UT samples obtain Fcrit of 4.066181 and F of 0.411606 . When the ultrasonic bath is conducted, shock out wave through the liquid cause high-speed collision which promote micro coating occur on the FeCrAl foil.

Table 5. Statistical analysis of after ultrasonic bath technique (UB).

\begin{tabular}{|c|c|c|c|c|}
\hline Source of Variation & $d f$ & $M S$ & $F$ & $F$ crit \\
\hline Between Groups & 3 & $1.5 \mathrm{E}-06$ & 0.130165 & 4.120312 \\
\hline Within Groups & 8 & $1.15 \mathrm{E}-05$ & & \\
\hline Total & 11 & & & \\
\hline
\end{tabular}


Various groups in this research is divided into 4 such as Initial, cycle 1, cycle 2 and cycle 3 groups which have the same value of the df of 3 and 8 . The standard deviation of all data in every group and every method show the differences which indicated that the fluctuate condition when oxidizing in temperature of $1100{ }^{\circ} \mathrm{C}$ occurs. The SD of UB initial is 0.0019 , cycle 1 is 0.0019 , cycle 2 is 0.0019 and cycle 3 is 0.0018 . The SD for UT samples initial is 0.0048 , cycle 1 is 0.0051 , cycle 2 is 0.0043 and cycle 3 is 0.0038 . The SD for EP samples initial is 0.0382 , cycle 1 is 0.0362 , cycle 2 is 0.0159 and cycle 3 is 0.0131 . High standard deviation means that the data that resulted by the parameter is more significant effect as compared to lower standard deviation. However, all methods is recommended to produce the catalytic converter material with high oxidation properties.

Table 6. Statistical analysis of after combination of ultrasonic bath and electroplating (UT).

\begin{tabular}{|l|c|c|c|c|}
\hline \multicolumn{1}{|c|}{ Source of Variation } & $d f$ & $M S$ & $F$ & $F$ crit \\
\hline Between Groups & 3 & $2.54 \mathrm{E}-05$ & 0.411606 & 4.066181 \\
\hline Within Groups & 8 & $6.18 \mathrm{E}-05$ & & \\
\hline Total & 11 & & & \\
\hline
\end{tabular}

\section{Conclusion}

FeCrAl was coated by $\gamma-\mathrm{Al}_{2} \mathrm{O}_{3}$ using 3 various methods and it can be concluded that the coated material has higher oxidation resistance as compared to the uncoated material. The smallest mass change of coated material is $0.3 \mathrm{wt} \%$ for UB $3 \mathrm{~h}$ and UT $3 \mathrm{~h}$ and $0.6 \mathrm{wt} \%$ for EP $3 \mathrm{~h}$. Parabolic rate constant is linear with mass change value. The significance data is approved by statistical analysis for all the data shown that Fcrit $>F$. Consistency data is established that all parameter and all procedure that conducted in this research is in-line with the fundamental methods.

The authors would like to thank the Ministry of Higher Education Malaysia and Universiti Tun Hussein Onn Malaysia (UTHM) through the funding supported FRGS grant under No Vot. 1216 and then Centre for Graduate Studies - UTHM.

\section{References}

1. H. Santos, M. Costa, Energ. Convers. Manage., 49, 291 (2008)

2. H.S. Gandhi, G.W. Graham, R.W. McCabe, J. Catal., 216, 433 (2003)

3. A. Firdianto. Ultrasonic Treatment with Nickel Electroplating Combined with Oxidation for Developing Gamma-Alumina Washcoat on Fe-Cr-Al Substrate (Diss. UTHM, Batu Pahat, 2012)

4. J. Kaspar, P. Fornasiero, N. Hickey, Catal. Today, 77, 419 (2003)

5. K. Reszka, D. Murzynski, J. Rakoczy, Vacuum, 83, S224 (2009)

6. Shi Jin Shuai, Jian Xin Wang, Chem. Eng. J., 100, 95 (2004)

7. Bode Hans, Material Aspect in Automotive Catalytic Converter. (Wiley-VCH, Chicago, 2002)

8. J.P. Dong, H.G. Kim, J.Y. Park, Y. Jung, J.H. Park, Y.H. Koo, Corros. Sci., 94, 459 (2015)

9. D.H. Kim, B.Y. Yu, P.R. Cha, W.Y. Yoon, J.Y. Byun, S.H. Kim, Surf. Coat. Technol., 209, 169 (2012)

10. N.A. Badarulzaman, S. Purwadaria, A.A. Mohamad, Z.A. Ahmad, Ionics, 15, 603 (2009) 
11. J. Liwei, M. Shen, J. Wang, Surf. Coat. Technol., 201, 7159 (2007)

12. Z. Bajram, M. Hodnett, A. Carroll, Ultrasonics, 44, 73 (2006)

13. A. Ryosuke, M. Atobe, T. Fuchigami, Ultrason. Sonochem., 13, 19 (2006)

14. E. Hadi, Z. Morteza, Indian J. Eng. Mater. S., 18, 314 (2011) 